\title{
Pesticides in Greenhouse Runoff, Soil and Plants: A Screening
}

\author{
Ketil Haarstad*, John Bavor and Roger Roseth
}

Bioforsk Soil and Environment-F. A. Dahls v. 20, N-1432 Ås, Norway, Australia

\begin{abstract}
A research has been undertaken studying pesticide losses from areas with intense agricultural and horticultural productions such as vegetables, cotton, pot plants and flowers, taking grab and composite samples including using passive SPMD samplers in ditches, creeks, rivers and groundwater, in addition to greenhouse and imported products. Pesticides were frequently found, occasionally in high concentrations, both in the products and in the environment. Endosulfan could be detected in the products, in pot soil and in plants, and also in the water samples, even in areas where it has been banned for several decades. Dilute concentrations of endosulfan can be detected by using passive samplers.
\end{abstract}

Keywords: Agricultural pollutants, greenhouse runoff, pesticides, passive sampling, sampling strategies.

\section{INTRODUCTION}

Some productions, such as vegetables and flowers, occasionally use large amounts of pesticides and often with relatively toxic compounds [1]. In greenhouses the options for growth control are greater, still the application of pesticides is often high. Flooding episodes increase the danger of loosing bio-accumulating, toxic and persistent compounds to the environment. The risk from bio-accumulating pesticides can be difficult to verify at low concentrations. One example is endosulfan $(6,7,8,9,10,10$-hexachloro-1,5,5a,6,9,9a-hexahydro-6,9methano-2,4,3-benzodioxathiepine-3-oxide), used to control insects in e.g. cotton production. In Norway endosulfan has been banned since 1998, but in the European Union, two member states, Italy and France, are using and exporting it [2]. In 2008, France exported 24 tonnes of the pesticide to African countries such as Mali, Senegal, and Burkina Faso. Endosulfan has been found in rivers downstream for agriculture and horticulture [3], in wetland sediments treating landfill leachate at a concentration of $14.5 \mu \mathrm{g} / \mathrm{kg}$ [4], in 5 out of 72 screened greenhouses for flower production [5], and in tropical agricultural wetland sediments in ca $1.0 \mu \mathrm{g} / \mathrm{kg}$ [6]. Endosulfan has been found to bioaccumulate in eel [7]. Up to $2 \%$ of the applied endosulfan could be lost through run-off from cotton productions, subsequently found in concentrations from $2 \mu \mathrm{g} / \mathrm{l}$ to $45 \mu \mathrm{g} / \mathrm{l}$ [8]. Experiments with spiked water showed that $>90 \%$ of applied endosulfan were removed in wetland systems [9], and to a lesser degree during soil biodegradation [10], although open dams are found to be more efficient the wetlands in removing cotton pesticides [11].

Our objective is to screen the occurrence of pesticides typically used in greenhouse productions, both in the greenhouse, in the products and in the environment. A special emphasis has been focused on endosulfan, using a passive water sampler. A number of ditches, creeks, small and have been analyzed for a selection of relevant compounds, using both grab and composite water samples, including pas

*Address correspondence to this author at the University of Western Sydney, Richmond, NSW, Australia; Tel: +4792846290; Fax: +4763009210; E-mail: Ketil.Haarstad@bioforsk.no

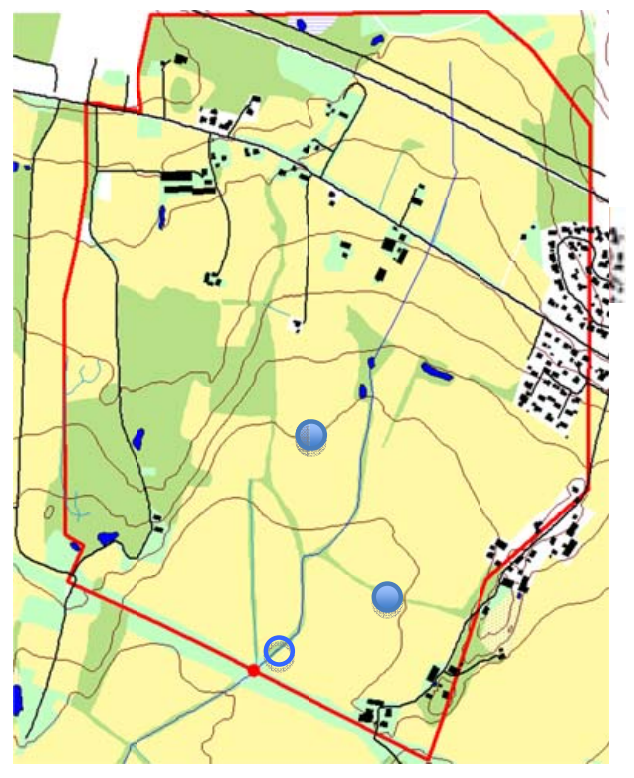

Fig. (1). Map showing the outdoor sampling locations in Heia, South Norway. Open circle $=$ creek sampling point. Blue filled circles=groundwater wells.

large streams, and groundwater downstream greenhouses sive semi-permeable membrane devices (SPMD, see Methods) samplers. In addition soil, plants and flowers were also sampled, from the commercially available products. The findings are discussed.

\section{MATERIALS AND METHODS}

This study was carried out by sampling indoor greenhouse locations in Norway, and outdoor runoff from greenhouse and vegetable growing areas in southern Norway and in Western Sydney, New South Wales, Australia.

\section{Outdoor Productions, Norway}

A $1.7 \mathrm{~km}^{2}$ area (Fig. 1), of which $62 \%$ is agricultural, ca. $60 \mathrm{~km}$ south-east of Oslo has been sampled since 1994. The area consists of clay soils with overlying $0-2 \mathrm{~m}$ thick silty 
Table 1. Water Characteristics at the Heia Sampling Location*

\begin{tabular}{|c|c|c|c|c|c|c|c|}
\hline Place & Tot-P & Tot-N & EC & pH & Fe & Water level & Elevtion \\
\hline \hline & $\mathrm{mg} / \mathrm{L}$ & $\mathrm{mg} / \mathrm{L}$ & $\mathrm{mS} / \mathrm{m}$ & - & $\mathrm{mg} / \mathrm{L}$ & Mbs. & Masl. \\
\hline Creek & 0.55 & 17.8 & 23 & 6.6 & - & 16.3 \\
\hline Well 1 & 0.78 & 4.1 & 60.3 & 7.3 & 32.5 & 1.03 & 21.2 \\
\hline Well 3 & 0.95 & 4.5 & 109 & 7.5 & 0.65 & 1.04 & 17.0 \\
\hline
\end{tabular}

*Mean values, no. of samples varies from 1 to 14 . masl.=meter above sea level. mbs.=meter below surface

sand. Grab- and composite samples have been collected from the creek, and grab samples have also been taken from two groundwater wells. Composite water samples are collected automatically on a volume proportional basis in all catchments $[12,13]$. The sampling moment is determined as a function of the measured discharge. Each time a predetermined volume of water has passed the measurement location, a small sample of water is taken and stored in a sample container at $5^{\circ} \mathrm{C}$. Changes in discharge lead to changes in sampling intensity, hence an increase in discharge results in increased sampling intensity while a decrease in discharge leads to the opposite.

Table 2. Locations and Water Types at the Sampled Greenhouses, Norway

\begin{tabular}{|c|c|c|c|c|}
\hline Location & Latidtude & Elevation & Tot-N & Tot-P \\
\hline & & masl.* & $\mathrm{mg} / \mathrm{l}$ & $\mathrm{mg} / \mathrm{l}$ \\
\hline 1 Oslo & $\mathrm{N} 59^{\circ} 54^{\prime} 40$ & 100 & $4.4-125$ & $0.3-4.5$ \\
\hline 2 Grimstad & $\mathrm{N} 58^{\circ} 20^{\prime} 49$ & 50 & $3.2-16$ & $0.2-4.2$ \\
\hline 3 Sandnes & $\mathrm{N} 58^{\circ} 51^{\prime} 38$ & 30 & $2.2-11.8$ & $0.2-1.6$ \\
\hline 4.Trondheim & $\mathrm{N} 63^{\circ} 25^{\prime} 60$ & 100 & $3.9-5.9$ & 0.1 \\
\hline
\end{tabular}

*masl.=meter above sea level.

The composite water sample in the container represents the average concentration during the sampling period. By default, composite water samples are collected for analysis every 14 days, however during periods with high runoff conditions samples can be collected more frequently. Volume proportional water sampling gives very satisfactory results compared to other sampling methods and is recommended in load estimation studies [14-16].
The wells are $3 \mathrm{~m}$ deep, made of stainless steel with the bottom $1 \mathrm{~m}$ screened with the objective to sample the top of the ground water. The main characteristics of the water types are presented in Table $\mathbf{1}$. The wells have been emptied one week before sampling. The sampling locations are in a triangle ca. $300 \mathrm{~m}$ apart (Fig. 1) at $59^{\circ} 222^{\prime} 50$ '” (Table 2).

\section{Indoor Commercial Plant Productions and Plant and Flower Imports, Norway}

A total of 12 grab samples of water from greenhouses were taken from four areas in Norway (Table 2) downstream sand traps, ditches, ponds and creeks and stored in one litre dark glass bottles for pesticide analyses, and in 0.5 litres polyethylene (PE) bottles for analyses of nutrients. The local samples were shipped to the laboratory the same day as collected, whereas regional samples were shipped by mail overnight. The samples were taken either within the drainage of the greenhouse, or at $20 \mathrm{~m}$ to $700 \mathrm{~m}$ downstream the greenhouse locations, mixing with surface runoff of size $0,2 \mathrm{~km}^{2}$ to $10 \mathrm{~km}^{2}$. The main production in the greenhouses are flowers, potting cultures and imported plants, but also tomato and cucumber.

\section{Outdoor Sampling, Sydney}

A total of seven locations were chosen in the Hawkesbury area where there are intense productions of flowers, plants and vegetables, see location and description in Tables 3 and 4, and Fig. (2). The locations surround the river Hawkesbury and one of its tributaries, the South Creek, and includes ditches, holding dams and small creeks. The sampling was carried out in March, 2010. The SPMD samplers were collected after one week in the water.

Table 3. Sampling Locations, Sydney

\begin{tabular}{|c|c|c|c|c|c|c|}
\hline & $\begin{array}{l}\text { Latitude } \\
\text { South }\end{array}$ & $\begin{array}{c}\text { Elevation } \\
(\text { masl) }\end{array}$ & $\begin{array}{c}\text { Flow } \\
\left(\mathbf{m}^{3} / \mathbf{d}\right)[17]\end{array}$ & pH- & $\begin{array}{c}\mathrm{EC} \\
\mathrm{mS} / \mathrm{m}\end{array}$ & $\begin{array}{c}\text { Turbidity } \\
\text { TU }\end{array}$ \\
\hline 1 & $33^{\circ} 36^{\prime} 24$ & 13 & Ditch & 7.4 & 44.6 & 5.5 \\
\hline 2 & $33^{\circ} 35^{\prime} 49$ & 15 & Dam & 7.4 & 29.5 & 46 \\
\hline 3 & $33^{\circ} 35^{\prime} 9$ & 7 & Dam & 7.1 & 42.6 & 29 \\
\hline 4 & $33^{\circ} 34^{\prime} 4$ & 5 & Dam & 7.4 & 31.3 & 22 \\
\hline 5 & $33^{\circ} 31^{\prime} 52$ & 12 & 570000 & 7.5 & 24.5 & 2.4 \\
\hline 6 & $33^{\circ} 34^{\prime} 22$ & 14 & Creek & 7.3 & 57.8 & 11 \\
\hline 7 & $33^{\circ} 40^{\prime} 39$ & 9 & 110000 & 7.4 & 68.2 & 10 \\
\hline
\end{tabular}


Table 4. Description of Sampling Locations, and the Number of Samples Used at Each Location

\begin{tabular}{|c|c|c|c|}
\hline Location & Name & Description & No. of SPMDs \\
\hline 1 & $\begin{array}{c}\text { Galston strawberries } \\
\text { (Crowleys Lane, Agnes Banks) }\end{array}$ & Dam in drainage next to bridge ca. $1 \mathrm{~m}$ deep & 3 \\
\hline 2 & $\begin{array}{c}\text { Galson strawberries } \\
\text { (Yarramundi Lane, Agnes Banks) }\end{array}$ & Canal next to road ca. $30 \mathrm{~cm}$ deep & 1 \\
\hline 3 & $\begin{array}{l}\text { Cuppits rd. Richmond flats } \\
\text { (Cupitts Lane, Cornwallis) }\end{array}$ & Dam next to bridge. Green algae. Ca. $50 \mathrm{~cm}$ deep & 1 \\
\hline 4 & $\begin{array}{c}\text { Freemans ridge } \\
\text { (Gorricks Lane, Freemans Reach) }\end{array}$ & Dam next to road & 3 \\
\hline 5 & $\begin{array}{c}\text { Hawkesbury river } \\
\text { (Coromandel Road, Ebenezer) }\end{array}$ & $\begin{array}{l}\text { Next to camping site } \\
\text { Downstream Ebenezer churc }\end{array}$ & 1 \\
\hline 6 & $\begin{array}{c}\text { North Richmond } \\
\text { (Terrace Road, North Richmond) }\end{array}$ & Between 2 bridges, $1.8 \mathrm{~m}$ deep & 1 \\
\hline 7 & $\begin{array}{c}\text { South creek } \\
\text { (Richmond Road, Windsor Downs) }\end{array}$ & Under bridge Richmond rd & 1 \\
\hline
\end{tabular}



Fig. (2). Map showing the sampling points in Western Sydney [22].

Table 5. Characteristics* of the Analyzed Pesticides, Mainly from [18, 19] and [20]

\begin{tabular}{|c|c|c|c|c|c|c|}
\hline Pesticide & $\begin{array}{c}\mathrm{K}_{\mathrm{oc}} \\
\mathbf{L o g}\end{array}$ & $\begin{array}{c}T_{1 / 2} \\
\text { days }\end{array}$ & $\begin{array}{c}\text { Water Solubility } \\
\mathrm{mg} / \mathrm{l}\end{array}$ & $\begin{array}{c}\text { pKa } \\
-\end{array}$ & $\begin{array}{c}\text { PNEC } \\
\mathrm{mg} / \mathrm{l}\end{array}$ & Type \\
\hline 2,6-dichlorbenzamid & -1.15 & 5800 & 2730000 & & 21 & $\mathrm{~m}$ \\
\hline $2,4-\mathrm{D}$ & 1.68 & 14 & 900000 & 2.87 & 2.2 & $\mathrm{~h}$ \\
\hline acephate & 0.30 & 3 & 790000000 & -1.87 & & $\mathrm{i}$ \\
\hline acetamipirid & 0.80 & & & & & i \\
\hline Aclonifen & 3.93 & 50 & 1400 & & 0.25 & $\mathrm{~h}$ \\
\hline alfacypermethrin & 4.76 & & 10 & & 0.0001 & $\mathrm{i}$ \\
\hline AMPA** & & & & & 452 & $\mathrm{~m}$ \\
\hline atrazine & 2.5 & 45 & 33000 & 1.74 & 0.40 & $\mathrm{~h}$ \\
\hline atrazine-desetyl** & & & & & 0.40 & $\mathrm{~m}$ \\
\hline azoxystrobin & 2.76 & 110 & 6000 & & 0.95 & $\mathrm{f}$ \\
\hline bentazone & 1.65 & 35 & 570000 & & 80 & $\mathrm{~h}$ \\
\hline
\end{tabular}


Table 5. contd....

\begin{tabular}{|c|c|c|c|c|c|c|}
\hline Pesticide & $\begin{array}{c}\mathrm{K}_{\mathrm{oc}} \\
\log \end{array}$ & $\begin{array}{c}T_{1 / 2} \\
\text { Days }\end{array}$ & $\begin{array}{c}\text { Water Solubility } \\
\text { Mg/l }\end{array}$ & $\begin{array}{c}\text { pKa } \\
-\end{array}$ & $\begin{array}{c}\text { PNEC } \\
\mathrm{Mg} / \mathrm{l}\end{array}$ & Type \\
\hline boksalid & 2.88 & & & & & $\mathrm{f}$ \\
\hline carbendazim & 2.35 & & 8000 & 4.48 & & $\mathrm{f}$ \\
\hline clopyralid & 1.56 & 13 & 9000 & 2.30 & & $\mathrm{~h}$ \\
\hline DDT & 5.60 & 2000 & 1 & & 0.05 & $\mathrm{i}$ \\
\hline deltamethrin & 7.0 & & & & & $\mathrm{i}$ \\
\hline diazinone & 3.15 & 27 & 60000 & & 0.0034 & $\mathrm{i}$ \\
\hline deltamethrin & 7.0 & & & & & $\mathrm{i}$ \\
\hline Endosulfan & 4.09 & 150 & 330 & & 0.050 & i \\
\hline endosulfan-sulfat & & & & & & $\mathrm{m}$ \\
\hline esfenvalerate & 3.70 & 42 & 2 & & 0.0001 & $\mathrm{i}$ \\
\hline ETU ** & 3.00 & & & & 2 & $\mathrm{~m}$ \\
\hline fenamidone & 0.59 & & & & & $\mathrm{f}$ \\
\hline fenarimol & 2.88 & 28 & 15000 & & & $\mathrm{f}$ \\
\hline fenazakvin & 4.42 & & & & & $\mathrm{i}$ \\
\hline fenheksamid & 3.53 & & & & & $\mathrm{f}$ \\
\hline fenmedipham & & 50 & 6000 & & & $\mathrm{~h}$ \\
\hline flusilazol & 3.22 & & & & & $\mathrm{f}$ \\
\hline glyphosate & 3.3 & 37 & 10000000 & 5.70 & 28 & $\mathrm{~h}$ \\
\hline hexythiazox & 3.82 & & & & & $\mathrm{a}, \mathrm{v}$ \\
\hline imazalil & 3.6 & 150 & 180000 & & 3 & $\mathrm{f}$ \\
\hline imidacloprid & 2.30 & 30 & 514000 & & & $\mathrm{i}$ \\
\hline indoxacarb & 3.7 & & & & & $\mathrm{i}$ \\
\hline iprodion & 2.82 & 50 & 14000 & & 17 & $\mathrm{f}$ \\
\hline iprovalicarb & 2.08 & & 17800 & & & $\mathrm{f}$ \\
\hline isoproturon & 0.85 & 28 & 65000 & & 0.32 & $\mathrm{~h}$ \\
\hline klofentesin & 1.56 & 40 & 3 & & & $\mathrm{i}, \mathrm{a}$ \\
\hline kloprofam & 3.95 & 30 & 89 & & 5 & $\mathrm{~h}$ \\
\hline kresoxim-methyl & 2.40 & 34 & 2 & & 0.7 & $\mathrm{f}$ \\
\hline lamba-cyhalotrin & 5.25 & 240 & 5 & & 0.0002 & $\mathrm{i}$ \\
\hline linuron & 2.70 & 82 & 75000 & & 0.56 & $\mathrm{~h}$ \\
\hline mancozeb & 3.78 & 43 & 6000 & & & $\mathrm{f}$ \\
\hline MCPA & 2.04 & 25 & 825000 & 3.09 & 13 & $\mathrm{~h}$ \\
\hline mancozeb & 3.78 & 43 & 6000 & & & $\mathrm{f}$ \\
\hline mecoprop & 1.60 & 21 & 860000 & 3.11 & 44 & $\mathrm{~h}$ \\
\hline metalaxyl & 2.23 & 80 & 7100000 & & 120 & $\mathrm{f}$ \\
\hline
\end{tabular}


Table 5. contd....

\begin{tabular}{|c|c|c|c|c|c|c|}
\hline Pesticide & $\begin{array}{l}\mathbf{K}_{\mathrm{oc}} \\
\mathbf{L o g}\end{array}$ & $\begin{array}{r}T_{1 / 2} \\
\text { Days }\end{array}$ & $\begin{array}{c}\text { Water Solubility } \\
\mathrm{Mg} / \mathrm{l}\end{array}$ & $\begin{array}{c}\text { pKa } \\
-\end{array}$ & $\begin{array}{c}\text { PNEC } \\
\mathrm{Mg} / \mathrm{l}\end{array}$ & Type \\
\hline metamidophos & -0.1 & & 1200000000 & & & $\mathrm{i}$ \\
\hline metamitron & 0.83 & 30 & 1700000 & & 10 & $\mathrm{~h}$ \\
\hline metiocarb & 2.82 & 24 & 27000 & & & $\mathrm{i}$ \\
\hline metomyl & 2.63 & & 5800000 & & & $\mathrm{i}$ \\
\hline metribuzine & 1.58 & 30 & 1050000 & 1.00 & 0.18 & $\mathrm{~h}$ \\
\hline penconazole & 2.8 & & 73000 & 1.51 & 6.90 & $\mathrm{f}$ \\
\hline pikoxystrobin & 2.95 & 20 & & & & $\mathrm{i}$ \\
\hline pirimifosmethyl & 3.66 & & & & & $\mathrm{i}$ \\
\hline pirimicarb & 1.36 & 10 & 3000000 & & 0.09 & $\mathrm{i}$ \\
\hline prochloraz & 3.88 & 130 & 34000 & 3.80 & 0.32 & $\mathrm{f}$ \\
\hline profenophos & 3.3 & 2 & 28000 & & & $\mathrm{i}$ \\
\hline propachlor & 1.90 & 12 & 613000 & & 0.29 & $\mathrm{~h}$ \\
\hline propiconazole & 2.80 & 83 & 100000 & 1.10 & 0.13 & $\mathrm{f}$ \\
\hline prothioconazole & 1.4 & 1 & 9000 & 6.9 & & $\mathrm{f}$ \\
\hline pyraklostrobin & 2.88 & & & & & $\mathrm{f}$ \\
\hline pyrimetanil & 2.84 & 17 & 121000000 & 3.52 & 16 & $\mathrm{f}$ \\
\hline simazine & 2.10 & 89 & 6200 & 1.60 & 0.42 & $\mathrm{~h}$ \\
\hline spinosad & 4.4 & 1 & & & & $\mathrm{i}$ \\
\hline spiroksamin & & & 470000 & & & $\mathrm{f}$ \\
\hline tebukonazol & 3 & & 32000 & & 23 & $\mathrm{f}$ \\
\hline terbutylazine & & & 9000 & & 0.2 & $\mathrm{~h}$ \\
\hline thiabendazole & 4 & 403 & 5000 & 4.7 & 2.4 & $\mathrm{f}$ \\
\hline thiametoxan & 1.81 & 229 & 4100000 & & & $\mathrm{f}$ \\
\hline trifloxystrobin-methyl & 3.38 & 1 & 610 & & & $\mathrm{f}$ \\
\hline triforine & 2.70 & 21 & 30000 & & & $\mathrm{f}$ \\
\hline
\end{tabular}

* $\mathrm{K}_{\mathrm{oc}}=$ soil organic carbon partition coefficient. $\mathrm{T}_{1 / 2}=$ field or soil halflife. PNEC is the environmental risk limit (Ludvigen \& Lode, 2004).Type: a=Acaricide, $\mathrm{f}=$ Fungicide, $\mathrm{h}=$ Herbicide, $\mathrm{i}=$ Instecticide, $\mathrm{m}=$ Metabolite, $\mathrm{v}=$ Growth inhibitor. $* *$ Metabolites. AMPA=degraded from glyphosate, atrazin-desethyl=degraded from atrazin,, ETU = ethylenethiourea, degraded from mancozeb.

\section{Chemical Analyses and Compounds}

The characteristics of the pesticides included in the analyses are shown in Table $\mathbf{5}$. The adsoption coefficient is listed as the the organic carbon partition $\left(\mathrm{K}_{\mathrm{oc}}\right)$, the half-life $\left(T_{1 / 2}\right)$ is either from water, groundwater or soil. All values are selected based on a $\mathrm{pH}$ of 7 , if variation with $\mathrm{pH}$ is listed. Pesticides in water samples were analyzed according to the method GC-MULTI M60, with detection limits varying between $0.02 \mu \mathrm{g} / \mathrm{L}$ to $0.05 \mu \mathrm{g} / \mathrm{L}$. In addition one sample from the ground water Wells 1 and 3 were analysed by the mulitmethods M85 and M86. The extraction for the M60analysis was as follows: The water samples $(200 \mathrm{~mL})$ were extracted twice with dichloromethane $(50 \mathrm{~mL}+25 \mathrm{~mL})$ after addition of $2.5 \mathrm{~g} \mathrm{NaCl}$. Ditalimfos, quintozene and triphenyl phosphate were used as internal standards and added at the start of extraction. The extracts were combined, dried over anhydrous $\mathrm{Na}_{2} \mathrm{SO}_{4}$, concentrated to near dryness and diluted to $1.0 \mathrm{~mL}$ with acetonitrile. Analysis of the acetonitrile extract was performed by gas chromatography with mass spectrometric detection (GC-MS) in scan mode and liquid chromatography with QQQ detection (LC-MS/MS).
The GC-MS analysis for the M85 method was as follows: An Agilent 6890 GC equipped with a 5973 MS detector and a Gerstel PTV-injector was used. The column was HP-5MS, $30 \mathrm{~m} \times 0.25 \mathrm{~mm}$ i.d., $0.25 \mu \mathrm{m}$ film thickness with a deactivated fused silica retention gap $(2-10 \mathrm{~m} \times 0.25 \mathrm{~mm}$ i.d.), and helium was used as carrier gas. The oven was programmed from $65{ }^{\circ} \mathrm{C}(1.5 \mathrm{~min})$ at a rate of $15{ }^{\circ} \mathrm{C} / \mathrm{min}$ to $120{ }^{\circ} \mathrm{C}(0$ $\min )$, then $20{ }^{\circ} \mathrm{C} / \mathrm{min}$ to $160{ }^{\circ} \mathrm{C}(0 \mathrm{~min})$, then $4{ }^{\circ} \mathrm{C} / \mathrm{min}$ to $270{ }^{\circ} \mathrm{C}(0 \mathrm{~min})$, and finally $10^{\circ} \mathrm{C} / \mathrm{min}$ to $300^{\circ} \mathrm{C}(2 \mathrm{~min})$. Injections $(15 \mu \mathrm{L})$ were made using solvent vent at $80^{\circ} \mathrm{C}$ for $0.4 \mathrm{~min}$, then $720^{\circ} \mathrm{C} / \mathrm{min}$ to $250^{\circ} \mathrm{C}(2 \mathrm{~min})$. The temperatures of the MS detector was $280{ }^{\circ} \mathrm{C}$ (transfer line), $230{ }^{\circ} \mathrm{C}$ (ion source), and $106^{\circ} \mathrm{C}$ (quadropol).

The LC-MS/MS analysis for the M86 method was carried out on an Agilent $1200 \mathrm{LC}$ with an Agilent 6410B MS/MS-detector (ES+ mode) with an Eclipse Plus C18 column, $100 \mathrm{~mm} \times 2.1 \mathrm{~mm}$ i.d. as follows: Particles: $1.8 \mu \mathrm{m}$. Mobile phase: A: Methanol with $5 \mathrm{mM}$ ammonium formate $+0.01 \%$ formic acid B: Milli-Q water with $5 \mathrm{mM}$ ammonium formate $+0.01 \%$ formic acid. Gradient (B): $90 \%$ at 0 $\min \rightarrow 90 \%$ at $2 \mathrm{~min} \rightarrow 0 \%$ at $18 \mathrm{~min} \rightarrow 0 \%$ at $20 \mathrm{~min} \rightarrow$ $90 \%$ at $20.1 \mathrm{~min}$ and hold $12 \mathrm{~min}$ (total time $32 \mathrm{~min}$ ). Flow: $0.3 \mathrm{ml} / \mathrm{min}$. Column temp: $50{ }^{\circ} \mathrm{C}$ 



Fig. (3). Pesticide water solubility (top, left, $\mathrm{mg} / \mathrm{l}$ ), half-life $\mathrm{T}_{1 / 2}$ (days, top, right) and partition coefficient (log $1 / \mathrm{kg}$, bottom) of the analyzed pesticides. $\mathrm{f}=$ fungicide, $\mathrm{h}=$ herbicide, $\mathrm{i}=$ inseciticide, $\mathrm{i}, \mathrm{a}=$ insecticide and acaricide, $\mathrm{m}=$ metabolite.

Table 6. Pesticides Found in the Western Sydney Area $(\mu \mathrm{g} / \mathrm{l})$

\begin{tabular}{|c|c|c|c|c|c|c|c|c|c|c|}
\hline Location & Atrazine* & pirimi-Carb & Kresoxim & Imazalil & Meta-Mitron & Pro-Chloraz & Tebu-Conazole & Azoxy-Strobin & Simazin & Sum \\
\hline 1. Ditch & 0.47 & & & & & & & & & 0.47 \\
\hline 2. Dam & 0.02 & 0.04 & 0.02 & 0.22 & 0.04 & 0.04 & 0.03 & & & 0.41 \\
\hline 3. Dam & & & & & & & & & & n.d \\
\hline 4. Dam & & 0.02 & & & & & & 0.11 & & 0.13 \\
\hline 5. River & 1.6 & & & & & & & & 0.04 & 1.64 \\
\hline 6. Creek & 0.01 & & & & & & & & & 0.01 \\
\hline 7. River & 0.08 & & & & & & & & 0.02 & 0.1 \\
\hline
\end{tabular}

*Including degradation products

The analyses were performed at the Norwegian Institute for Agricultural and Environmental Research, Plant Health and Plant Protection division, Pesticide Chemistry Section. The laboratory is accredited according to EN ISO/IEC 17025 for the analysis of pesticide residues in water and food of plant origin. The pesticides used in the batch and column filter material experiments were of analytic grade (Dr. Ehrenstorfer, Germany).

SPMDs with a total length of $91.4 \mathrm{~cm}$ and a triolein lipid content of $1 \mathrm{~mL}(0.95 \mathrm{~g})$ were used. The SPMDs were cleaned before analysis by dipping in hexane for 20-30 seconds, dried with paper, scrubbed with a nailbrush under cold tap water, dipped in $1 \mathrm{M} \mathrm{HCl}$ in 20 to 30 seconds, rinsed in cold tap water and dried, and finally dried by wiping with paper soaked in acetone. The extraction was carried out by adding the SPMD to a bottle with $230 \mathrm{ml} \mathrm{n}$-hexane, together with the internal standards, resting for 18 hours in the dark. The extract is then transferred to an evaporating tube, the bottle is then rinsed with $60 \mathrm{ml} \mathrm{n}$-hexane, shaken at low frequency for 6 hours. The extracts are then combined, vaporized and dissolved in $2.5 \mathrm{ml}$ dichloromethane. The GPC cleanup consisted of a $0.45 \mu \mathrm{m}$ filtration following by the GPC injection and collection of the extracts that are vapor- ised to $1 \mathrm{ml}$ and transferred to a GC-vial. The GC was set in a SIM mot with a PTV injector and a HP-5MS column with a $3 \mathrm{~m}$ x $0.25 \mathrm{~mm}$ inner diameter $0.25 \mathrm{~mm}$ film.

Fig. (3) shows that the insecticides have a slightly higher average water solubility compared to the fungicides, that are slightly higher than the herbicides, contrary to the fact that insecticides used to being hydrophobic. Some of the insecticides have a very high water solubility. The spreading in solubility is, however, much higher for insecticides and fungicides. The order is also approximately the same for pesticide half-life and partition.

\section{Statistical Analyses}

Selected results are presented as box plots and means created with the software JMP [21].

\section{RESULTS AND DISCUSSION}

\section{Outdoor Sampling, Sydney}

A total of 9 compounds were found in the water samples based on grab samples from Western Sydney, the herbicide atrazine being most frequently found in the water samples, and from most of the locations (Table 6). Surprisingly, con- 



Fig. (4). Pesticide water solubility (top, left, $\mathrm{mg} / \mathrm{l}$ ), half-life $\mathrm{T}_{1 / 2}$ (days, top, right) and partition coefficient (log $1 / \mathrm{kg}$, bottom) of the pesticides detected in the water samples from Western Sydney. See also Fig. (3).

Table 7. Endosulfan in SPMD Samplers and in Water Samples Downstream Greenhouses

\begin{tabular}{|c|c|c|c|c|c|c|c|}
\hline \multirow[t]{2}{*}{ SPMD } & \multirow[t]{2}{*}{ Location } & \multicolumn{4}{|c|}{ SPMD Endosulfan (Mg) } & \multirow[b]{2}{*}{ Total mg/kg lipid } & \multirow{2}{*}{$\begin{array}{c}\text { Water } \\
\mu \mathrm{g} / 1\end{array}$} \\
\hline & & alfa & beta & sulphate & Total & & \\
\hline 1 & 1 & 0.02 & 0.02 & 0.02 & 0.06 & 63 & \\
\hline 2 & 1 & 0.01 & 0.02 & 0.02 & 0.05 & 53 & \\
\hline \multirow[t]{2}{*}{3} & 1 & & & & n.d. & & \\
\hline & Sum 1 & 0.03 & 0.04 & 0.04 & 0.11 & 116 & \\
\hline 4 & 2 & & & & n.d. & & \\
\hline 5 & 3 & & & & n.d. & & \\
\hline 6 & 4 & & & 0.01 & 0.01 & 11 & \\
\hline 7 & 4 & & & 0.05 & 0.05 & 53 & \\
\hline \multirow[t]{2}{*}{8} & 4 & & & 0.05 & 0.05 & 53 & \\
\hline & Sum 4 & & & 0.11 & 0.11 & 116 & \\
\hline 9 & 5 & & & & n.d. & & \\
\hline 10 & 6 & & & & n.d. & & \\
\hline \multirow[t]{3}{*}{11} & 7 & & & 0.01 & 0.01 & 11 & \\
\hline & Norway 1 & & & & & & $0.02-0.09$ \\
\hline & Norway 2 & & & & & & 1.13 \\
\hline
\end{tabular}

sidering the water flow in the river, the water sample from the Hawkesbury at Location 5 had the highest concentration found in the study area, with $1.3 \mu \mathrm{g} / \mathrm{l}$ atrazine. Assuming the pesticides concentrations in Table $\mathbf{6}$ are representative for the mean value for the rivers, the Hawkesbury is annually carrying 923 $\mathrm{g}$ pesticides, while the river $\mathrm{S}$. Creek is transporting $11 \mathrm{~g}$.

Location 2, a ditch, and 5, the Hawkesbury river, had lower electrical conductivity (EC) values than the other locations (Table 3), Location 2 also showed the highest turbidity. In these waters a lot of the EC can be expected to come from fertilizer application. The $\mathrm{pH}$-values of the water samples are high, indicating an influence from limestone or the use of lime as fertilizer in the area. High $\mathrm{pH}$-values favor the ionization of compounds with low pKa-values (Table 5).

The pesticides detected in Sydney shown in Fig. (4) clearly show a much lower water solubility, half-life and partition, compared to the values in Fig. (3).

\section{Endosulfan}

Endosulfan was detected in three of the 7 locations in Western Sydney. The endosulfan content of the SPMD samples varied between $11 \mu \mathrm{g} / \mathrm{kg}$ to $116 \mu \mathrm{g} / \mathrm{kg}$ (Table 7), highest 




Fig. (5). Sum pesticide concentration (mg/l) in grab (Well 1, Well 3 and grab (CG, left axis) and composite (CC, right axis) water samples from the creek Heia, Norway.

Table 8. Maximum Concentrations ( $\mu \mathrm{g} / \mathrm{l})$ of Pesticides Found in the Creek or in the Wells in Heia, Norway, and the Time of Sampling of the Sample Containing the Maximum Concentration

\begin{tabular}{|c|c|c|c|}
\hline Pesticide & Maximum Concentration & When & Where \\
\hline 2,6-dichlorbenzamid & 0.60 & July-00 & Creek \\
\hline aclonifen & 0.78 & June-08 & Creek \\
\hline alfacypermethrin & 0.01 & June-04 & Creek \\
\hline azoxystrobin & 0.58 & August-08 & Well \\
\hline bentazone & 6.90 & June-95 & Creek \\
\hline cyprodinil & 0.31 & November-10 & Well \\
\hline DDT & 0.06 & June-04 & Creek \\
\hline esfenvalerate & 0.06 & July-04 & Creek \\
\hline ETU & 3.00 & July-95 & Creek \\
\hline fenhexamid & 1.4 & July-08 & Creek \\
\hline fenmedipham & 2.2 & May-08 & Creek \\
\hline fenpropimorph & 12.0 & July-98 & Creek \\
\hline fluazinam & 2.2 & June-04 & Creek \\
\hline fluroxipur & 0.34 & May-07 & Creek \\
\hline glyphosate & 0.14 & November-06 & Creek \\
\hline
\end{tabular}


Table 8. contd....

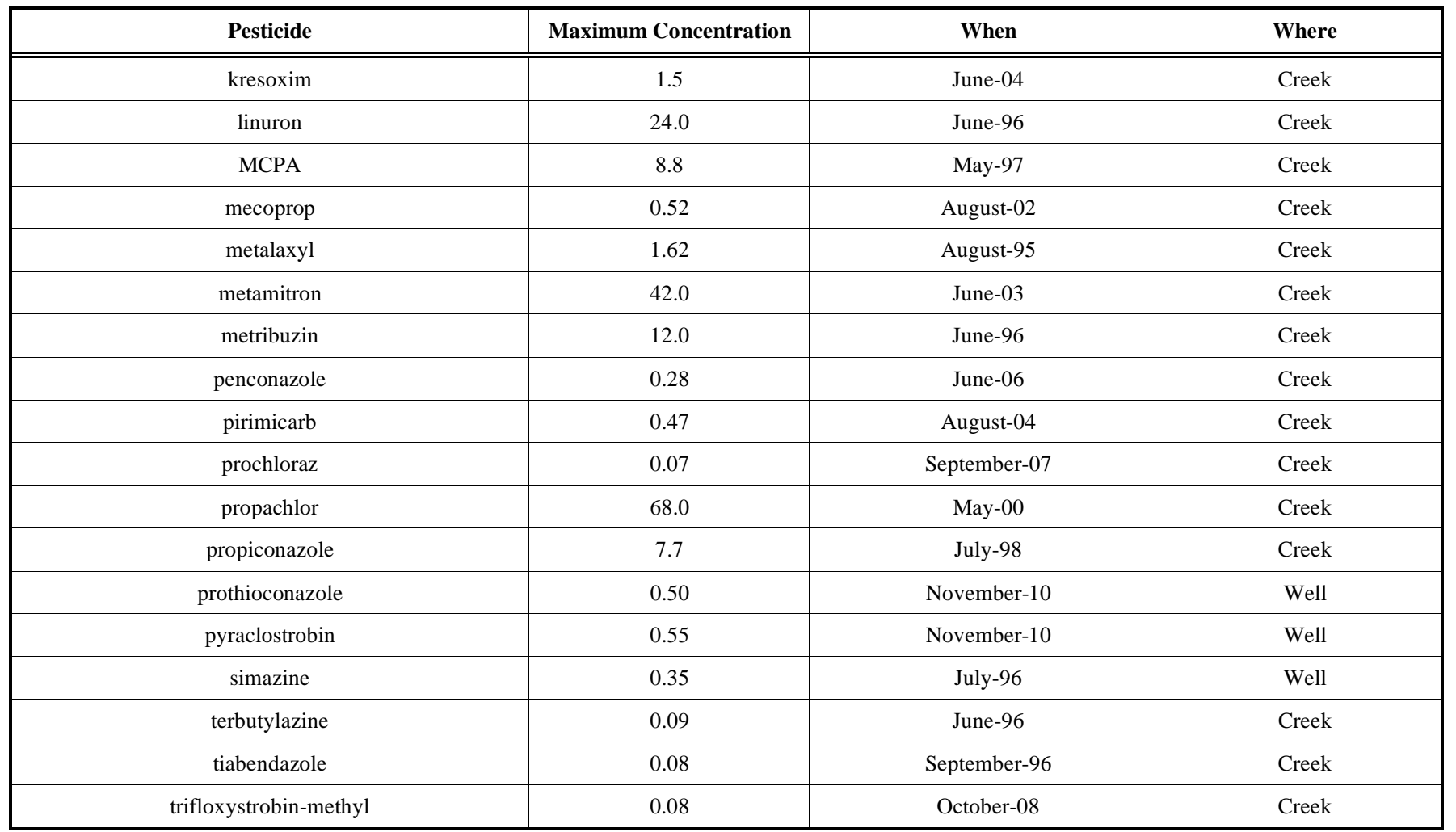
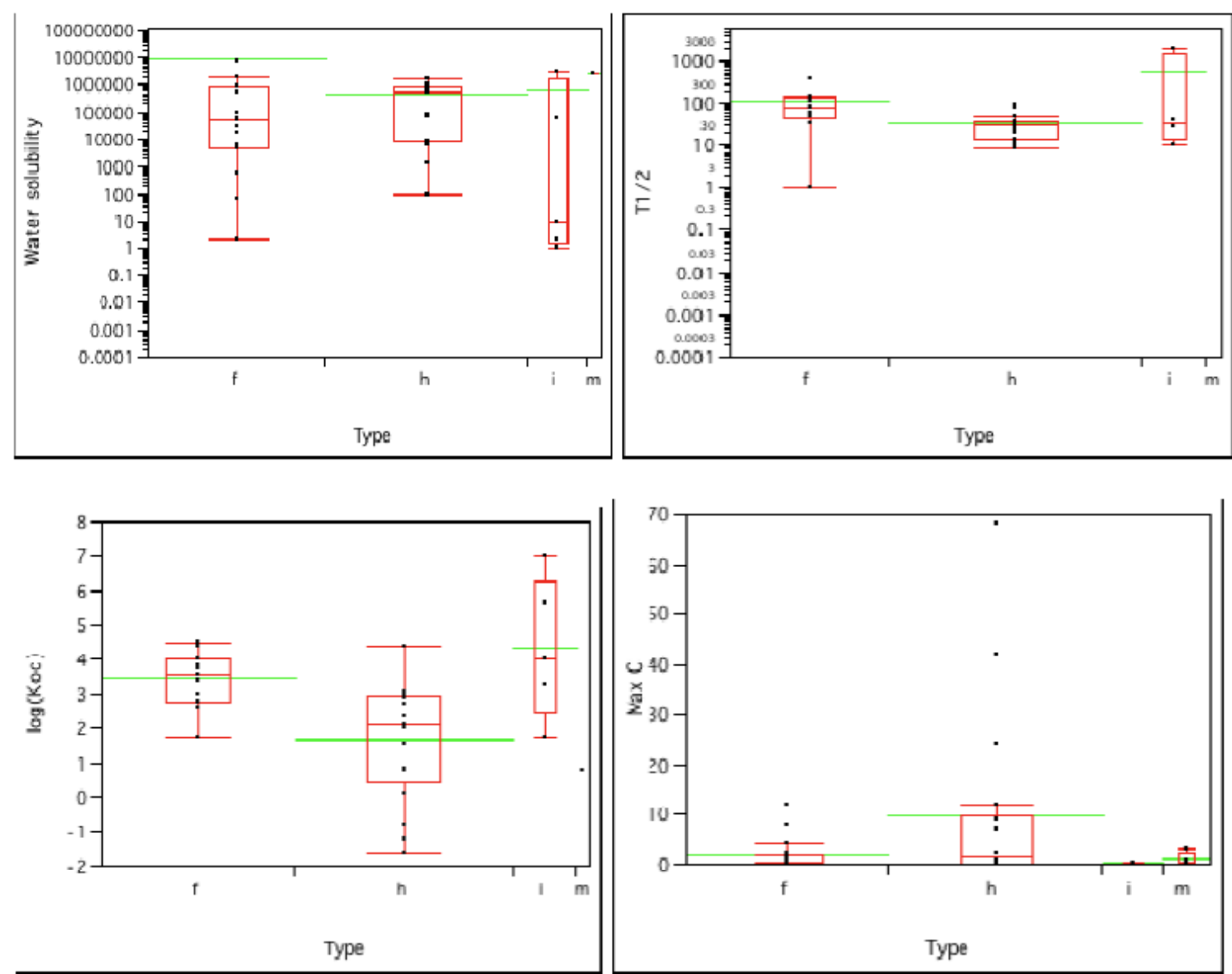

Fig. (6). Pesticide water solubility (mg/l) half-life $\mathrm{T}_{1 / 2}$ (days), organic partition coeffisient, and maximum concentration of the compounds found in the long-term monitoring downstream greenhouses in Norway. See also Fig. (3). 

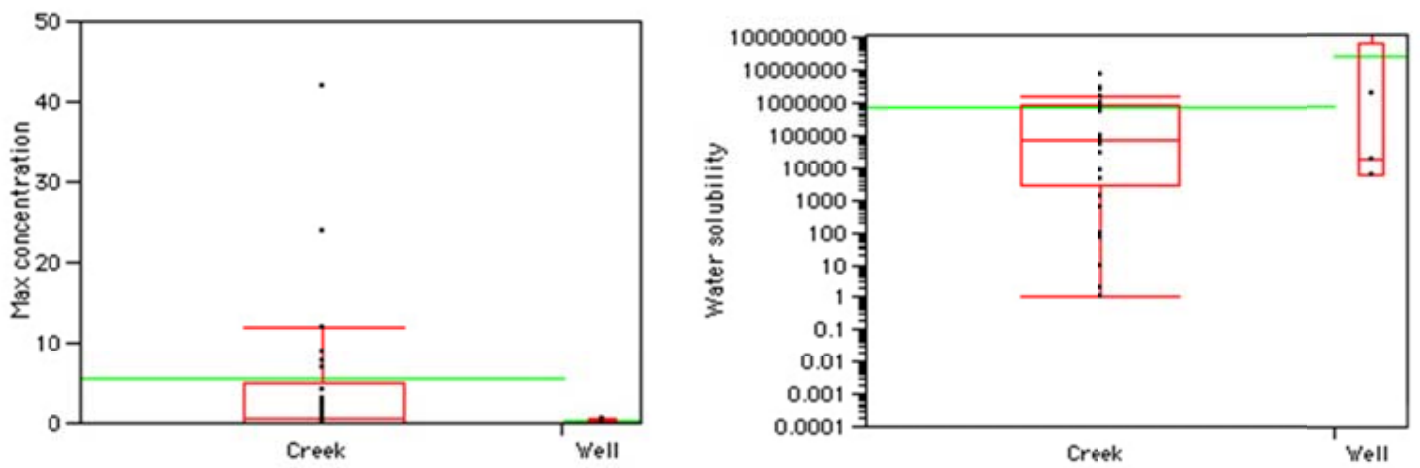

Fig. (7). Maximum pesticide concentration $(\mathrm{mg} / \mathrm{l})$ and water solubility of pesticides found in the longterm monitoring in creek and wells.

Table 9. Pesticides Detected in Greenhouse Products $(\mathrm{Mg} / \mathrm{kg})$

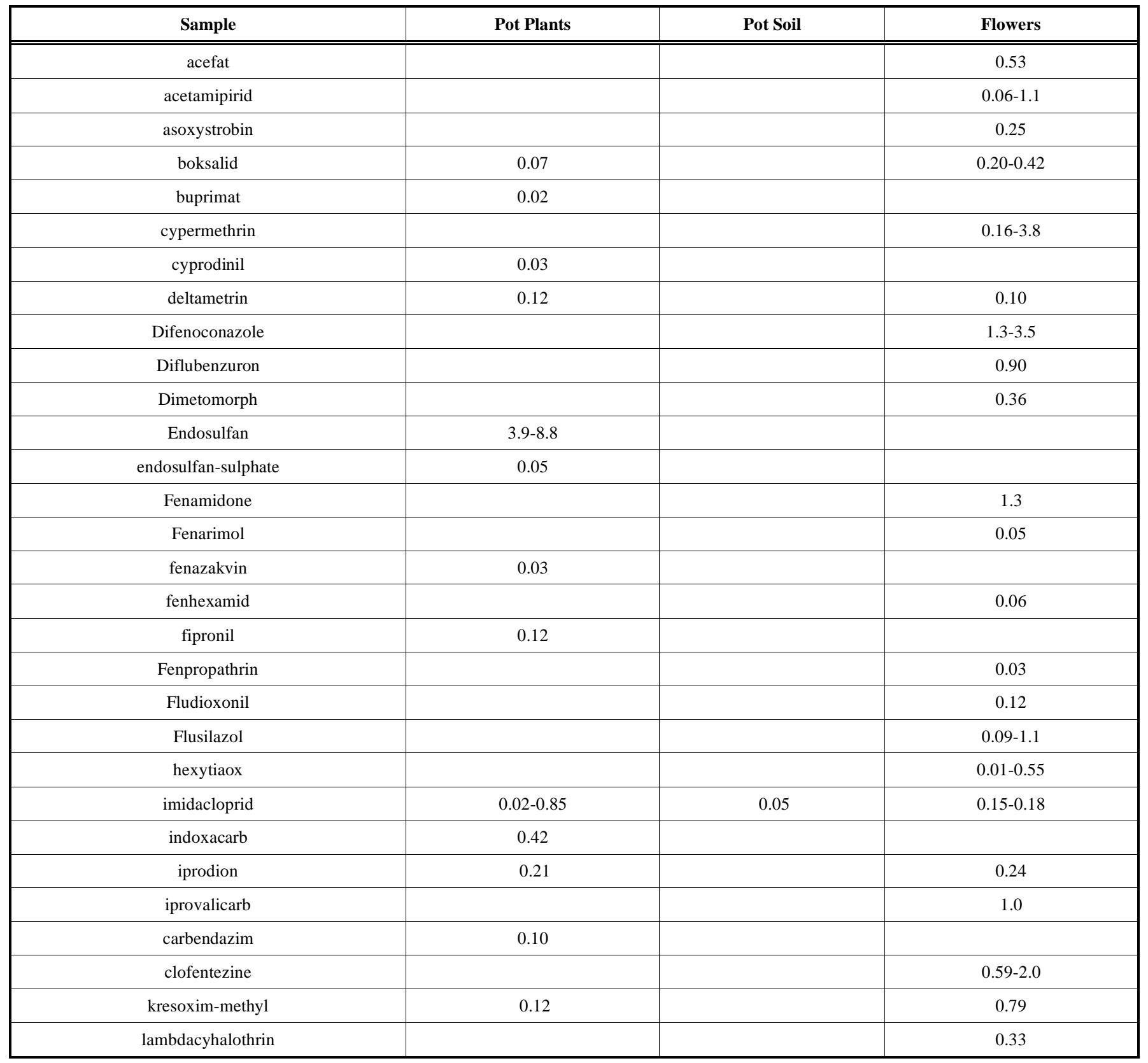


Table 9. contd...

\begin{tabular}{|c|c|c|c|}
\hline Sample & Pot Plants & Pot Soil & Flowers \\
\hline metalaxyl & 0.09 & 0.17 & \\
\hline metamidofos & & & 0.10 \\
\hline metiocarb & 0.47 & & \\
\hline metiocarb-sulfoxid & 0.56 & & \\
\hline methomyl & 0.09 & & \\
\hline metribuzin & 0.03 & & \\
\hline penkonazole & $0.02-0.06$ & & \\
\hline picoxystrobin & & & 0.07 \\
\hline pirimifosmethyl & $0.06-0.41$ & $0.13-2.2$ & \\
\hline pirimicarb & & 0.17 & 0.06 \\
\hline profenofos & & & 0.17 \\
\hline pyraklostrobin & & & $0.04-0.06$ \\
\hline pyrimetanil & $0.01-0.46$ & 0.20 & 0.74 \\
\hline spinosad & 0.11 & 0.17 & 0.04 \\
\hline spiroxamine & & & $0.04-5.1$ \\
\hline tiometoxam & & 0.77 & \\
\hline triforine & & & 0.43 \\
\hline
\end{tabular}

in Location 1 and 4, both dams next to the road. Also the sampler in the river S. Creek (7) showed some endosulfan. There seems to be equal amount of the endosulfan isomers alfa and beta, and the degradation product endosulfan sulphate (Table 7). There was no detection of endosulfan in the water samples from W. Sydney. In the water samples from Norway, detections of endosulfan varied from $0.02 \mu \mathrm{g} / \mathrm{l}$ to $1.13 \mu \mathrm{g} / \mathrm{l}$ (Table 7).

\section{Longterm Monitoring, Norway}

More than $90 \%$ of the samples in the creek contained detectable pesticide residues. The maximum concentration detected in the creek was almost twice the maximum found in the groundwater. The pesticide concentrations in the creek were found to have more regular seasonal peaks from 2004, see Fig. (5) and Table 8. Also the concentrations were higher in the groundwater (Well 1) before 2004, and higher in the creek after 2004. The data indicate that composite samples are better in detecting high concentrations than grab samples.

The electrical conductivity in the shallow groundwater was about 600 to $1000 \mathrm{mS} / \mathrm{cm}$ (Table 1), higher that the creek water in Western Sydney. The creek receives most of the nitrogen fertilizer run-off, but the groundwater in this area has the same concentrations of $\mathrm{P}$ as do the creek water. The groundwater in Well 1 is elevated indicating more reduced conditions at this location, although the groundwater level is the same.

For the pesticides detected in the long-term monitoring in the creek and in the groundwater, the insecticides and herbicides have a slightly lower average water solubility compared to the fungicides (Fig. 6). The spreading in solubility is large towards lower values for the insecticides. For half-life and organic partitioning the values are significantly higher for the insecticides, the herbicides having relatively low residence time in the environment. The highest concentrations are found for the herbicides.

The highest concentrations are also found in the creek (Fig. 7), also showing a higher mean concentration compared to the samples from groundwater. The average water solubilities of the compounds found in groundwater is, however, higher than those found in the creek.

\section{Indoor Productions and Imports, Norway}

The concentration of pesticides in flowers, pot plants and pot soil frequently was found at levels of several $\mathrm{mg} / \mathrm{kg}$, see Table 9, both for insecticides and fungicides, eg. endosulfan, cypermethrin, fenamidione, fluzilazol and iprovalicarb. Some concentrations exceed toxicity limit values. The high range concentrations in flowers are found in flowers imported from Africa.

For the pesticides detected in the monitoring of the indoor productions, the insecticides and fungicides have a slightly higher average water solubility compared to the herbicides (Fig. 8). The spreading in solubility is larger for the insecticides. For half-life the values are slightly higher for the insecticides, but this is not the case for the partition coefficient.

For the pot plants there seems to have been a shift from equal mean concentrations between fungicides and insecticides in the soil, to higher concentrations of insecticides in the pot plants (Fig. 9). For the flowers the highest concentrations that are found are fungicides.

When representing the different compounds with the average concentration found, it can be seen that the fungicides and insecticides occur at the same average concentar 

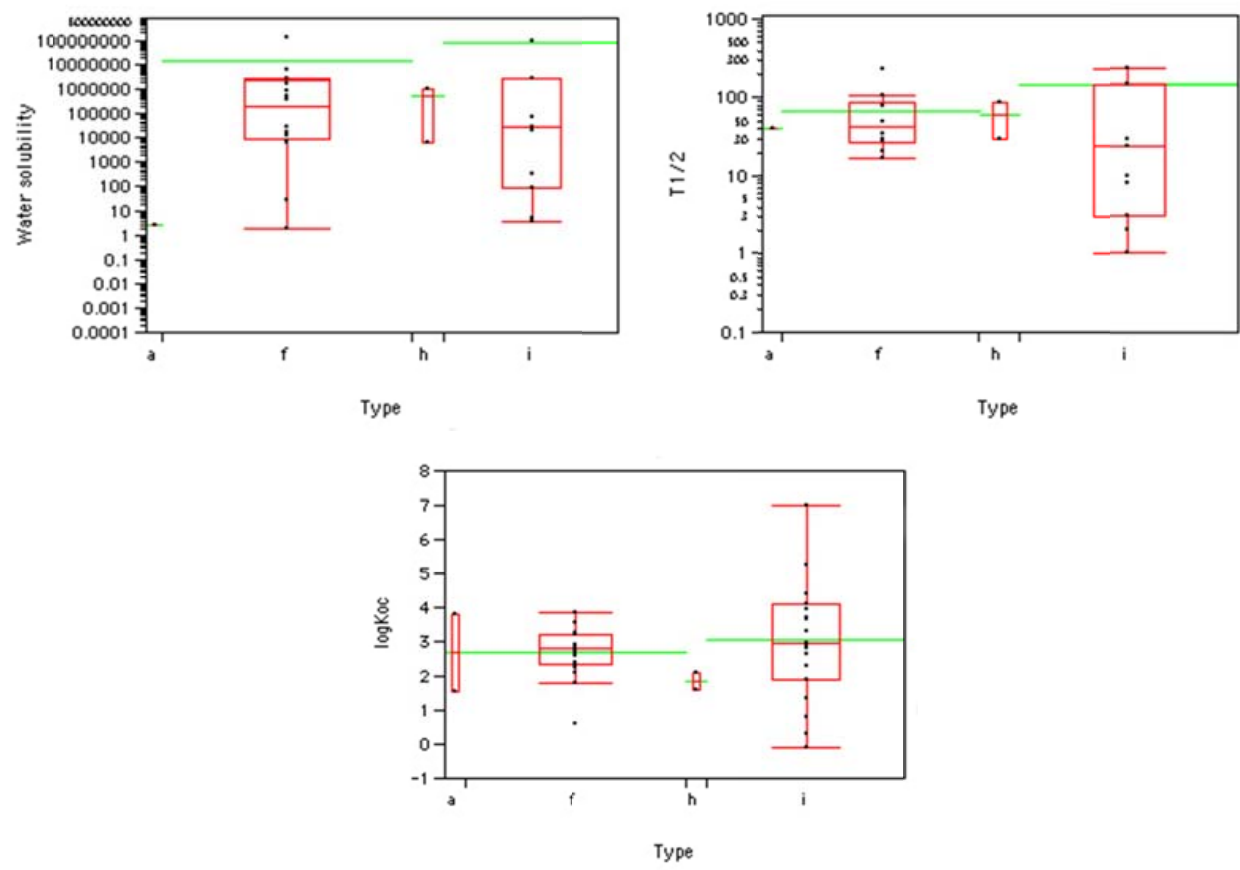

Fig. (8). Pesticide water solubility (top, left, $\mathrm{mg} / \mathrm{l}$ ), half-life $\mathrm{T}_{1 / 2}$ (days, top, right) and partition coefficient (log 1/kg, bottom) of the pesticides detected in pot plants, pot soil and flowers. See also Fig. (3).
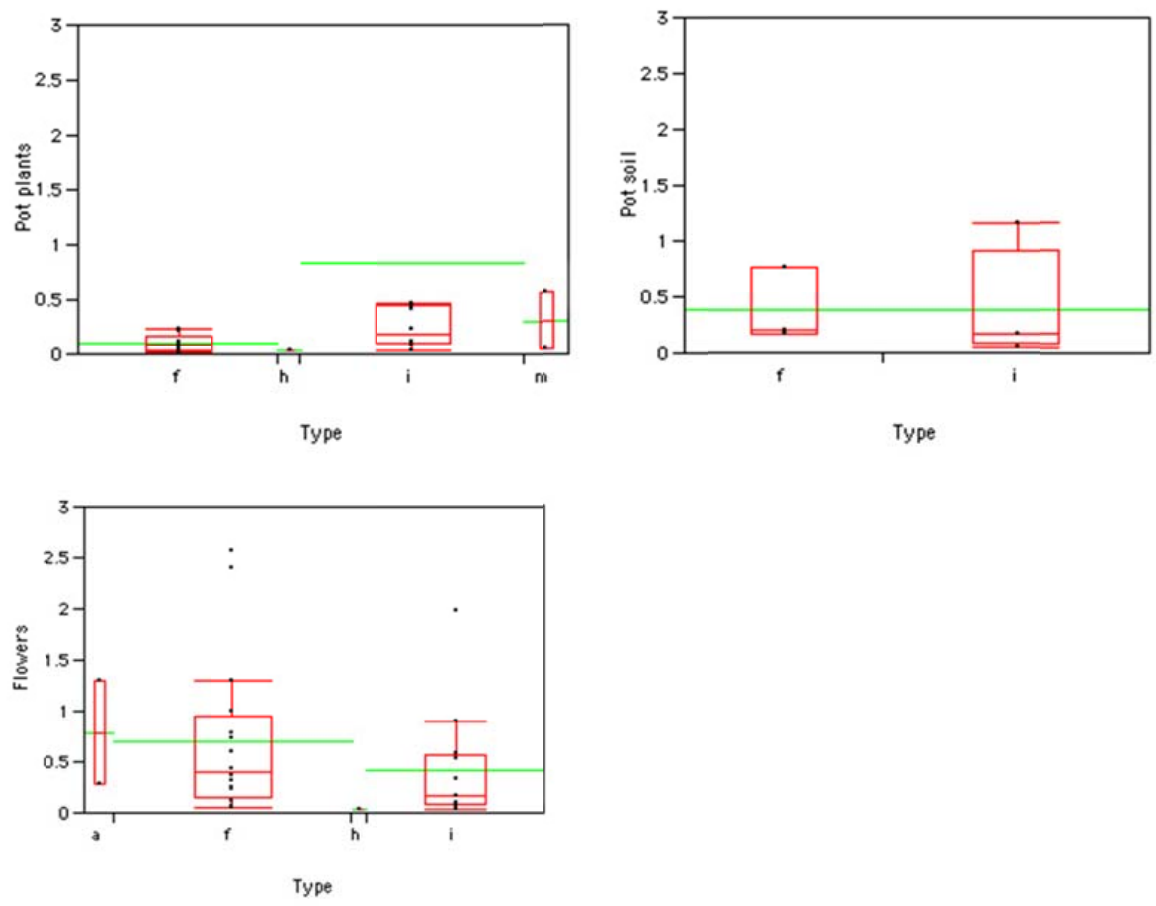

Fig. (9). Pesticide concentrations ( $\mathrm{mg} / \mathrm{kg}$ ) detected in domestic and imported pot plants, pot soil and in flowers. See also Fig. (3).

tion in pot soil (Fig. 9, top, right). In the pot plants the mean concentration of insecticides are higher, and in the flowers the mean concentration of fungicides are slightly higher.

In addition to the findings in Table 9 the following pesticides were detected in the runoff from the greenhouse areas: pyrimethanil, metalaxyl, cyprodinil, propiconazole, iprodion, azoxystrobin, pirimicarb, simazine, imazalil, prochloraz, isoproturon, endosulfan-sulfat, 2,6-dichlorbenzamid, metrib- uzin, propachlor, diazinone, vinclozolin and klorfenvinphos. The compounds in bold were detected in concentrations exceeding the PNEC value.

In addition endosulfan was detected in greenhouse products imported from Scandinavian countries; $3.9 \mathrm{mg} / \mathrm{kg}$ in solanum (a non-edible tomato plant, from Denmark), and 8.9 $\mathrm{mg} / \mathrm{kg}$ in potted soil (Roseth, 2009). In these samples endosulfan- $\alpha$ was the dominating constituent. 


\section{CONCLUSIONS}

- Of the 74 pesticides analysed the screening detected 44 pesticides in the run-off from greenhouses and vegetable productions.

- The characteristics of the analyzed compounds showed lower $\mathrm{K}_{\mathrm{oc}}$ values for the metabolites, for the water solubility the average values was higher than the interquartile range for all types of pesticides.

- The characteristics of the compounds found downstream greenhouse areas in Sydney had water solubility without extreme high values, and soil half-life values without extreme high values.

- The characteristics of the compounds found downstream greenhouse and vegetable growing areas in Norway had fungicides with extremely high water solubilities, but none showed soil half-life values that were extremely high, and showed high concentrations for herbicides in the creek, while groundwater samples showed compounds with high water solubilities.

- For plants, flowers and pot soil, herbicides and insecticides with high water solubilities were found, for flowers fungicides showed higher concentrations, and for pot soil insecticides showd higher concentrations.

- The highest concentrations in the water samples were detected in composite samples from creeks.

- There were high concentrations in imported flowers, and also in pot plants and pot soil.

- The highest concentration in the water samples was $68 \mu \mathrm{g} / \mathrm{l}$ for propachlor in spring.

- The groundwater samples also showed episodes of very high pesticide concentrations.

- High concentrations of endosulfan were found in products.

- In very dilute waters endosulfan can be detected using passive samplers.

\section{CONFLICT OF INTEREST}

None declared.

\section{ACKOWLEDGEMENT}

The JOVA data is collected with support from The Norwegian Department of Agriculture.

This paper is partly funded by Bioforsk within the basic grant for $\mathrm{R} \& \mathrm{D}$ provided by the Norwegian Research Council.

\section{REFERENCES}

[1] Roseth R, og Haarstad K. Pesticide runoff from greenhouse production. Water Sci Technol 2010; 61(6): 1373-81.
[2] IPEN Pesticide Working Group Secretariat, C/o Thanal, L-14, Jawahar Nagar, Kowdiar, Thiruvananthapuram - 695003 Kerala, India. Available from: www.thanal.org

[3] Miglioranza KSB, Aizpún De Moreno JE, Moreno VJ. Land-based sources of marine pollution: Organochlorine pesticides in stream systems. Environ Sci Pollut Res Int 2004; 11(4): 227-32.

[4] Haarstad K, Mæhlum T. Pesticides in Norwegian Landfill Leachates. Open Environ Biol Monit J 2008; 1: 8-15.

[5] The Norwegian Agricultural Authorities, Available from: http://landbrukstilsynet.mattilsynet.no/dokument.cfm?m_id=86\&d_ id $=1200$ [Accessed 25. May 2012].

[6] Hernández-Romero AH, Tovilla-Hernández C, Malo EA, BelloMendoza R. Water quality and presence of pesticides in a tropical coastal wetland in southern Mexico. Mar Pollut Bull 2004; 48(1112): $1130-41$.

[7] Ribeiro CA, Vollaire B, Sanchez-Chardi C, Roche H. Bioaccumulation and the effects of organochlorine pesticides, PAH and heavy metals in the Eel (Anguilla Anguilla) at the Camargue Nature Reserve, France Aquat Toxicol 2005; 74: 53-69.

[8] Kennedy IR, Sanchez-Bayo F, Kimber SW, Hugo L, Ahmad N. Off-site movement of endosulfan from irrigated cotton in New South Wales. J Environ Qual 2001; 30 (3): 683-97.

[9] Matamoros V, Puigagut J, Garci J, Bayona JM. Behavior of selected priority organic pollutants in horizontal subsurface flow constructed wetlands: A preliminary screening. Chemosphere 2007; 69: 1374-80. Available at: http://landbrukstilsynet.mattilsynet.no/dokument.cfm?m_id=86\&d_id=1200).

[10] Arshad H, Hussain S, Saleem M. Optimization of environmental parameters for biodegradation of alpha and beta endosulfan in soil slurry by Pseudomonas aeruginosa. J Appl Microbiol 2007; 104: 364-70.

[11] Rose MT, Crossan AN, Kennedy IR. Dissipation of cotton pesticides from runoff water in glasshouse columns. Water Air Soil Pollut 2007; 182: 207-18.

[12] Deelstra J, Øygarden L. Measurement of runoff. In: Øygarden L, Botterweg $\mathrm{P}$, Eds. Measuring runoff and nutrient loss from agricultural land in nordic countries. Nordic Council of Ministers: TemaNord 1998; pp. 13-26.

[13] Deelstra J, Vagstad N, Øygarden L. Sampling technique and strategy. In: Øygarden L, Botterweg P, Eds. Measuring runoff and nutrient loss from agricultural land in nordic countries. nordic council of ministers: Tema Nordic 1998; pp. 27-35.

[14] Rekolainen S, Posch M, Kama“ ri J, Ekholm P. Evaluation of the accuracy and precision of annual phosphorus load estimates from two agricultural basins in Finland. J Hydrol 1991; 128: 237-55.

[15] Haraldsen TK, Stålnacke P. Methods for water quality sampling and load estimation in monitoring of Norwegian agricultural catchments. Nordic Hydrol 2005; 37: 81-92.

[16] Schleppi P, Waldner AW, Fritschi B. Accuracy and precision of different sampling strategies and flux integration methods for runoff water: comparison based on measurements of the electrical conductivity. Hydrol Process 2006; 20: 395-410.

[17] Bickford \& Smith, 2006. Available at: (http://nest.su.se/mnode/Australia/HawkNep/hawknepbud.htm). [Accessed October 2011].

[18] Tomlin, C. The Pesticide Manual. $10^{\text {th }}$ ed. Cambridge, UK: The Royal Society of Chemistry 1994.

[19] Extoxnet. Extension Toxicology Network, Pesticide Information Profiles, archived at Oregon State Universityhttp. Available at: www.extoxnet.orst.edu [Accessed 2012].

[20] Pan. The Pesticide Action Network (PAN) Pesticide. The database and website are updated and enhanced by Pesticide Action Network North America (PANNA). Available at: http: //www.pesticideinfo.org [Accessed 2012].

[21] JMP, 2002. JMP 5.0. www.jmpdiscovery.com.

[22] Source imagery TerraMetrics Inc, Colorado, USA, Available at: https://collab.itc.virginia.edu/wiki/toolbox/Satellite\%20Imagery.ht $\mathrm{ml}$ [Accessed 2012]. 